\title{
CORRESPONDENCE
}

\section{Computer code: more credit needed}

As a microbiologist who has published work based on in-house computer code, I empathize with the laments in your News Feature (Nature 467, 775-777; 2010). However, its emphasis on more training for scientists and students fails to consider a downstream issue retaining the talent afterwards.

From personal experience, there is a common perception that computational analysis is just a tool to enable 'real' discoveries on the bench. Hence, there is little incentive to brush up on computerrelated skills. A few graduate students from my laboratory have invested time and effort to become respectable programmers, despite their lack of a background in computer science, but they became disillusioned when they found that their hard work was considered to be of secondary importance to the science.

These talented individuals have since left for careers in finance, management and information technology, where the same programming knowhow and problem-solving skills are highly appreciated.

They now enjoy shorter hours, comparable pay and greater job security than a tenure-track assistant professor.

The corollary of Nick Barnes's observation in World View that "most professional computer software isn't very good" (Nature 467, 753; 2010) is that good programmers regardless of their scientific background - are in demand everywhere. Teaching programming skills and best practices to scientists may indeed improve the quality of

\section{ONATURE.COM}

Join in the code debate at:

go.nature.com/ed3hs| software, but the software in question might not necessarily be for scientific research. Herman Tse The University of Hong Kong, Hong Kong, htse@hkucc.hku.hk

\section{Computer code: incentives needed}

I don't expect to see major changes to scientists' habits about publishing their software without clear incentives for them to do so (Nature 467, 753; 2010).

Given that the present value system in science is based almost exclusively on the publication of journal articles, publishing software should help scientists to publish papers. Once journals require (or at least strongly encourage) authors to submit their code as supplementary material, scientists will learn the tools and techniques necessary to get their code into a publishable state, and their employers will grant permission to publish it.

As the reproducible-research movement has also been pointing out for a while, the quality of science is then likely to improve significantly.

Konrad Hinsen Centre de Biophysique Moléculaire (CNRS), France,

konrad.hinsen@cnrs-orleans.fr

\section{Computer code: a model journal}

As a one-time developer of codes for climate models (these days, I'm more of a user), I would like to draw your readers' attention to a peer-reviewed journal that explicitly tackles many of the issues Nick Barnes raises (Nature 467, 753; 2010).

The journal Geoscientific Model Development (www.geoscientificmodel-development.net) strongly encourages publication of modelling codes alongside detailed descriptions of models. It was founded because models are seldom subject to the same degree of scrutiny and peer review as the results they generate - even though modelling is central to research into climate science.

As Barnes so rightly states, model codes themselves are rarely or never published traditionally. Model descriptions often need scientific results for publication and so are pared to the minimum when they do appear. Issues of reproducibility, platform dependence, version proliferation and the real nittygritty of modelling all need to be addressed in the literature. Dan Lunt University of Bristol, UK,d.j.lunt@bristol.ac.uk

\section{Reviewer disclaims competing interest}

Michael Mann and colleagues intimate that I had an undeclared conflict of interest in reviewing Roger Pielke Jr's book The Climate Fix (Nature 467, 920; 2010), citing alleged connections between me and the George C. Marshall Institute in Arlington, Virginia, reputedly a centre of climate-change scepticism.

Contrary to the authors' assertions, I did not write a report for the Marshall Institute. My relationship with the institute consists solely of participation in a 90-minute discussion in 2006 concerning how Congress deals with scientific issues (see go.nature.com/epxft1). Also taking part were a former member of the congressional Office of Technology Assessment and a current senior official of the US National Research Council of the National Academy of Sciences.

The audience in 2006, as I recall, consisted mainly of congressional staff members. I did not mention climate change and I received no payment for my participation.
Science journalists in Washington DC are often invited to address meetings on science-policy issues. I have taken part in similar discussions under the auspices of the Brookings Institution, the American Association for the Advancement of Science, the Association of American Universities, the Association of American Medical Colleges, and at dozens of universities.

Daniel S. Greenberg Washington DC, USA, danielg523@aol.com

\section{More insights from Crick's lost letters}

As author of the 2009 book Francis Crick: Hunter of Life's Secrets, I congratulate Alexander Gann and Jan Witkowski for their detective work on the previously lost correspondence between Francis Crick and Maurice Wilkins (Nature 467, 519-524; 2010). This material is invaluable for biographers and historians.

The rediscovered correspondence affirms my judgement - based on letters preserved with successive typescripts of Watson and Crick's 1953 papers, now at the Wellcome Library in London - that Crick was very much in charge of events during this period. It also reveals the continuing strength of Wilkins' friendship with Crick, which in 1959 found expression in his pleading with Crick not to abandon Cambridge in favour of the United States.

Robert Olby University of

Pittsburgh, USA,

olbyr@comcast.net

CONTRIBUTIONS

Submissions to

Correspondence should be sent to correspondence@ nature.com. 